\title{
Effect of Dietary Vitamin E on Rumen Biohydrogenation Pathways and Milk Fat Depression in Dairy Cows Fed High-Fat Diets
}

\author{
J. Pottier, ${ }^{\star}$ M. Focant, ${ }^{\star}$ C. Debier, ${ }^{\star}$ G. De Buysser, ${ }^{\star}$ C. Goffe, ${ }^{*}$ E. Mignolet, ${ }^{\star}$ \\ E. Froidmont, $†$ and Y. Larondelle ${ }^{\star 1}$ \\ *Unité de Biochimie de la Nutrition, Faculté d'Ingénierie Biologique, Agronomique et Environnementale, \\ Université Catholique de Louvain, B-1348 Louvain-la-Neuve, Belgium \\ †Département Productions et Nutrition Animales, \\ Centre Wallon de Recherches Agronomiques, B-5030 Gembloux, Belgium
}

\begin{abstract}
Six lactating Holstein cows were assigned to a replicated Latin square design to test the effect of dietary vitamin $\mathrm{E}$ on milk fat depression and on the increased production of milk trans-10 C18:1 classically observed when feeding high doses of unsaturated fatty acids with low-fiber diets. Two diets (linseed diet and linseed diet $+12,000 \mathrm{IU}$ of vitamin E/d) were compared during 2 periods of $21 \mathrm{~d}$. The linseed diet presented a forageto-concentrate ratio of 50:50 and contained extruded linseed $(1.86 \mathrm{~kg} / \mathrm{d})$ and linseed oil $(190 \mathrm{~g} / \mathrm{d})$. It was conceived to favor the "trans-11 to trans-10 shift" (low structural value and high level of unsaturated fatty acids). Milk yield and protein content were not affected by the diets. Milk of cows fed the linseed diet presented the typical symptoms of milk fat depression associated with a shift in biohydrogenation pathways: low fat content and high level of trans-10 C18:1. However, the high dose of dietary vitamin $\mathrm{E}$ provided significantly increased milk fat content (by 17.93\%) and yield (by 15.56\%) and decreased trans-10 C18:1 content (by $47.06 \%$ ). In addition, it managed to significantly increase the daily yields of vaccenic (by 102.56\%) and rumenic acids (by 56.67\%). However, the sequence of administration of vitamin $\mathrm{E}$ influenced its effect, as vitamin $\mathrm{E}$ seemed to be more active in limiting the "trans-11 to trans-10 shift" when it was incorporated in the diet simultaneously with the fat. Once the shift had occurred, the subsequent addition of vitamin $\mathrm{E}$ was no longer able to completely counteract this process.
\end{abstract}

Key words: biohydrogenation, milk fat depression, oilseed, vitamin $\mathrm{E}$

\section{INTRODUCTION}

Addition of plant-derived oils as a source of unsaturated fatty acids (UFA) in the diet of dairy cows im-

Received April 22, 2005.

Accepted October 14, 2005.

${ }^{1}$ Corresponding author: larondelle@bnut.ucl.ac.be proves the rheological properties (higher spreadability) as well as the nutritional properties (lower level of hypercholesterolemic saturated fatty acids and higher level of UFA) of milk fat. It may also result in a higher conjugated linoleic acid (CLA) content. Rumenic acid (cis-9, trans-11 C18:2), the predominant CLA in milk, is suspected to reduce the incidence and growth of tumors, enhance immune function, and prevent atherosclerosis and diabetes (Belury, 2002).

Many experiments have been carried out to increase the CLA content of milk by feeding cows oil-rich diets. Unfortunately, the addition of unsaturated fat to cow feed has the disadvantage of increasing milk fat susceptibility to oxidation (Palmquist et al., 1993). Furthermore, it may result in progressive changes in the rumen environment, leading to decreased fiber digestion (Palmquist, 1984). This is associated with altered rumen biohydrogenation characterized by a shift in major biohydrogenation pathways: decreased formation of trans-11 C18:1 (vaccenic acid) and increased formation trans-10 C18:1 in the rumen (Griinari and Bauman, 1999). Because of the importance of vaccenic acid as the precursor of milk fat rumenic acid in the mammary gland, rumenic acid content eventually decreases in milk (Bauman et al., 2000).

Reduced milk fat is another important side effect of high-fat diets. This phenomenon, referred to as milk fat depression (MFD), is typically observed with lowfiber (LF) diets including high levels of concentrates (either readily digestible carbohydrates or unsaturated fat; Bauman and Griinari, 2003). Several theories have been proposed to explain MFD (Bauman and Griinari, 2003). However, currently, the most supported theory involves trans-10, cis-12 CLA as a direct inhibitor of milk fat synthesis in the mammary gland.

Charmley and Nicholson (1994) studied the effect of fat source on milk fat composition of cows receiving different levels of dietary vitamin E. They observed that dietary fat from micronized soybeans decreased milk fat concentration. However, a high concentration of vitamin $\mathrm{E}$ supplement in the diet (8,000 IU/d) eliminated 
the fat-depressing effect. Similarly, Focant et al. (1998) showed that a huge dietary vitamin $\mathrm{E}$ supplement $(9,600 \mathrm{IU} / \mathrm{d})$ prevented the drop in milk fat yield, as well as resistance to oxidation, which was induced by the incorporation of unsaturated fat-rich extruded linseeds and rapeseeds. Recently, Kay et al. (2005) observed that addition of $10,000 \mathrm{IU}$ of $\alpha$-tocopherol/d to a TMR increased milk fat content by $6 \%$.

The alleviating effect of vitamin $\mathrm{E}$ on MFD suggests that it could minimize the formation of trans-10 isomers in the rumen, because MFD is associated with high levels of those fatty acids in milk. Prevention of the biohydrogenation shift would then allow maintenance of both milk fat concentration and elevated level of rumenic acid in milk when plant oils or oilseeds are included in the diet. The present study aims to examine the effect of dietary supplementation with vitamin $\mathrm{E}$ on the production of trans-10 C18:1 and on MFD induced by feeding a high-UFA, LF diet.

\section{MATERIALS AND METHODS}

\section{Experimental Design}

This experiment has been approved by the Commission d'Ethique de l'Expérimentation Animale of the Université Catholique de Louvain. Six multiparous Holstein cows averaging $639 \pm 37 \mathrm{~kg}$ of BW, $99 \pm 32$ DIM, and producing $29.9 \pm 3.2 \mathrm{~kg}$ of milk/d (mean \pm $\mathrm{SD})$ at the beginning of the experiment were blocked for DIM in 2 groups and assigned to a replicated Latin square design with 2 treatments (linseed and linseed + vitamin E) and 2 periods of $21 \mathrm{~d}$. Before the beginning of the experiment, cows were fed a diet based of grass and corn silage with a complement of alfalfa and linseed meals. During the experiment, all cows were fed the same amount of one of the 2 experimental diets (Table 1). This amount was calculated to cover animal needs according to INRA standards (INRA, 1988). The linseed diet was a 50:50 forage-to-concentrate ratio on a DM basis and contained extruded linseed $(1.86 \mathrm{~kg} / \mathrm{d})$ and linseed oil (190 g/d). It was conceived to favor the trans11 to trans-10 shift (low structural value, high level of UFA). The linseed + vitamin E diet was similar to the linseed diet except that it was supplemented with $12,000 \mathrm{IU}$ of unprotected vitamin E/d added to the concentrates in the form of a powder containing 50\% allrac- $\alpha$-tocopheryl acetate (Roche Co., Brussels, Belgium). The dietary changes were made overnight. Cows were offered feed individually twice daily at 0830 and $1830 \mathrm{~h}$. Water was available at all times. Cows were milked twice daily at 0730 and $1730 \mathrm{~h}$.
Table 1. Ingredient composition of the diets

\begin{tabular}{llc}
\hline & Linseed & $\begin{array}{l}\text { Linseed }+ \\
\text { vitamin E }\end{array}$ \\
\cline { 2 - 2 } Corn silage & 9.56 & $(\mathrm{~kg}$ of DM/d) \\
Grain corn & 4.53 & 9.56 \\
Soybean meal & 2.69 & 4.53 \\
Nutex compact & 1.86 & 2.69 \\
Linseed oil $_{\text {Mineral and vitamin } \text { mix }^{2}}$ & 0.19 & 1.86 \\
Vitamin E preparation $^{3}$ & 0.29 & 0.19 \\
\hline
\end{tabular}

${ }^{1}$ Extruded commercial concentrate (Interagri-Dumoulin, Seilles, Belgium) made of linseed ( $60 \%$ of DM), wheat, field beans, sunflower cake, manioc, and linseed oil $(\mathrm{CP}=20.0 \%$ of $\mathrm{DM}$, crude fiber $=7.5 \%$ of DM, and fat $=23.0 \%$ of DM).

${ }^{2}$ Contained $79.0 \%$ crude ash, $21.0 \% \mathrm{Ca}, 7.0 \% \mathrm{P}, 5.0 \% \mathrm{Mg}, 4.0 \% \mathrm{Na}$, $0.6 \% \mathrm{Zn}, 0.3 \% \mathrm{Mn}, 0.3 \% \mathrm{Fe}, 0.13 \% \mathrm{Cu}, 600 \mathrm{IU}$ of vitamin $\mathrm{A} / \mathrm{g}, 120$ IU of vitamin $\mathrm{D}_{3} / \mathrm{g}$, and $0.5 \mathrm{mg}$ of vitamin $\mathrm{E} / \mathrm{g}$ (Interagri-Dumoulin).

${ }^{3}$ Contained $50 \%$ of all-rac- $\alpha$-tocopheryl acetate (Roche Co., Brussels, Belgium). The additional vitamin E supply in the linseed + vitamin $\mathrm{E}$ diet was, thus, $12 \mathrm{~g} / \mathrm{d}$.

\section{Sampling}

Milk samples from individual cows were collected on the last day of each period at the morning and evening milkings. These samples were used for the Latin square statistical analysis. Additional samples from each cow were taken separately the day before the beginning of the experiment and on $\mathrm{d} 7$ and 14 of each period to visualize the kinetics of the changes in the different parameters. Individual cow yield was measured automatically (Fullwood Packo, Ellesmere, UK). Samples of the diets were taken weekly and used for DM and nutrient analyses. Orts were recorded and sampled once daily for DM analysis.

\section{Analytical Procedures}

Milk samples were refrigerated at $4^{\circ} \mathrm{C}$. A portion of each sample was used for fat (Gerber, 1938) and CP (N $\times 6.37$ ) analysis (Commission des Communautés Européennes, 1985), and the rest of each sample was processed into butter and anhydrous milk fat to allow longterm storage. To obtain anhydrous milk fat, butter was frozen overnight and then melted and centrifuged at $400 \times g$ at $50^{\circ} \mathrm{C}$ for $15 \mathrm{~min}$. The upper phase was passed through filters (filter type 595, Schleicher \& Schuell, Dassel, Germany) filled with anhydrous $\mathrm{Na}_{2} \mathrm{SO}_{4}$ as a desiccant at $60^{\circ} \mathrm{C}$. The extracted fat was stored at $-20^{\circ} \mathrm{C}$ under $\mathrm{N}_{2}$ until analysis for fatty acids. Fatty acids were methylated in a solution of $\mathrm{KOH}$ in methanol $(0.1 \mathrm{~N})$ at $75^{\circ} \mathrm{C}$ for $60 \mathrm{~min}$, then in a solution of $\mathrm{HCl}$ in methanol $(1.2 \mathrm{~N})$ at $75^{\circ} \mathrm{C}$ for $15 \mathrm{~min}$, and finally extracted in hexane. Fatty acid methyl esters were quantified by gas chromatography (GC Trace ThermoQuest, Thermo- 
Finnigan, Milan, Italy) using a fused silica capillary column $(100 \mathrm{~m} \times 0.25 \mathrm{~mm}$ i.d. $\times 0.2-\mu \mathrm{m}$ film thickness, CP-Sil 88, Chrompack, Middelburg, The Netherlands). Injection was on column. Hydrogen was used as the carrier gas. Pressure was held constant at $160 \mathrm{kPa}$. The initial oven temperature was $80^{\circ} \mathrm{C}$, increased $25^{\circ} \mathrm{C} / \mathrm{min}$ to $175^{\circ} \mathrm{C}$ (held for $25 \mathrm{~min}$ ), then increased at $10^{\circ} \mathrm{C} / \mathrm{min}$ to $205^{\circ} \mathrm{C}$ (held for $10 \mathrm{~min}$ ), and finally decreased $20^{\circ} \mathrm{C} /$ $\min$ to $80^{\circ} \mathrm{C}$. The temperature of the flame ionization detector was maintained at $255^{\circ} \mathrm{C}$. Hydrogen flow rate to the detector was $25 \mathrm{~mL} / \mathrm{min}$; airflow was $350 \mathrm{~mL} /$ min. Each peak, except those of trans-10 C18:1 and trans 6 to trans-8 C18:1, was identified and quantified through comparison with pure methyl ester standards (Alltech Associates, Deerfield, IL, except CLA isomers from Nu-Chek Prep, Inc., Elysian, MN). Because no commercial standard is available for trans-10 C18:1, the concentration of the corresponding peak was calculated through comparison with the trans-11 C18:1 peak area (by multiplying the concentration of trans- 11 C18:1 by the trans-10 peak area-to-trans-11 peak area ratio). The same method has been applied for trans- 6 to trans-8 C18:1, which coelute. The validity of this method has been verified by applying it to the peak of trans-9 C18:1 and comparing this calculated concentration with the trans-9 C18:1 concentration determined through the use of the appropriate standard. For the determination of the different CLA isomers, $50 \mathrm{~mL}$ of raw milk was mixed with $10 \mathrm{~mL}$ of $25 \% \mathrm{NH}_{3}$ and left for $15 \mathrm{~min}$ at room temperature. The fatty acids were then extracted by adding first $50 \mathrm{~mL}$ of ethanol, then $60 \mathrm{~mL}$ of petroleum ether, and lastly $60 \mathrm{~mL}$ of pentane, shaking well in between. The organic phases were then washed 2 times with $60 \mathrm{~mL}$ of distilled water and dried over anhydrous $\mathrm{Na}_{2} \mathrm{SO}_{4}$; finally, organic solvents were evaporated. The fatty acids were methylated with $\mathrm{NaOCH}_{3}$ methanol as described in Yurawecz et al. (1998). The CLA analysis was performed on a $\mathrm{Ag}^{+}-$ HPLC (Gilson, Villiers le Bel, France) with 3 columns put in series $(250 \mathrm{~mm} \times 4.6 \mathrm{~mm}$ i.d. $\times 5-\mu \mathrm{m}$ particle size, silver ion-impregnated, Chromspher lipids, Chrompack) with UV detection at $233 \mathrm{~nm}$. The carrier liquid was acetonitrile and hexane (0.1:99.9, vol:vol), the flow was $1.06 \mathrm{~cm}^{3} / \mathrm{min}$, and the oven temperature was $25.1^{\circ} \mathrm{C}$.

Silage samples were lyophilized. All feed samples were ground in a mill (1-mm screen, Retsch, Dusseldorf, Germany) and analyzed for $\mathrm{DM}, \mathrm{OM}, \mathrm{CP}(\mathrm{N} \times 6.25)$, ether extract(Commission des Communautés Européennes, 1985), NDF and ADF (Goering and Van Soest, 1970), and $\alpha$-tocopherol (Brubacher et al., 1985). Lipids were extracted following the method of Folch modified by Christie (1982). Methylation and gas chromatogra- phy analyses were performed as described for milk samples.

\section{Statistical Analyses}

Based on the measurements on $\mathrm{d} 21$ of each period (milk yield, milk fat, milk protein, fatty acid, and CLA profiles in milk), ANOVA was performed for a replicated Latin square design using the GLM procedure of SAS (SAS Inst., Inc., Cary, NC) with the following model:

$$
\mathrm{Y}_{\mathrm{ijkl}}=\mu+\operatorname{cow}_{\mathrm{i}(\mathrm{l})}+\operatorname{diet}_{\mathrm{j}}+\operatorname{period}_{\mathrm{k}}+\operatorname{square}_{\mathrm{l}}+\mathrm{e}_{\mathrm{ijkl}}
$$

where $\mathrm{Y}_{\mathrm{ijkl}}$ is the dependent variable, $\mu$ is the overall mean, $\operatorname{cow}_{\mathrm{i}(1)}$ is the cow effect inside each square $(\mathrm{i}=1$, $2,3,4,5$, or 6$),$ diet $_{\mathrm{j}}$ is the effect of treatments $(\mathrm{j}=1$ or 2), period $_{k}$ is the effect of each period ( $k=1$ or 2 ), square 1 is the effect of square $l(l=1,2$, or 3$)$, and $e_{i j k l}$ is the experimental error. Differences were declared significant at $P<0.05$.

To account for pretrial differences between cows, ANOVA using the same model was also performed on the differences between the values on $d 21$ of each period and the values obtained from the pretrial measurement for each dependent variable. The results obtained with this approach were similar to those of the statistical analysis just described.

The correlation between milk fat and milk trans-10 C18:1 content was tested using all of the individual milk samples with the CORR procedure of SAS (SAS Inst., Inc.).

For each group, a one-tailed $t$-test was performed between the data of $d 21$ and 7 and the data of $d 42$ and 21 to highlight the increase or decrease of trans$11 \mathrm{C} 18: 1$ and trans-10 C18:1 during the 2 experimental periods.

\section{RESULTS AND DISCUSSION}

\section{Nutrient Intake}

Daily intakes are summarized in Table 2 . They were very similar between the 2 diets, as the only difference was the vitamin $\mathrm{E}$ supplement. Intakes of $\mathrm{ADF}$ and NDF were intentionally low. Combined with a high intake of UFA (931 $\mathrm{g} / \mathrm{d}$ on average), it was intended to favor the shift in biohydrogenation patterns. Vitamin E intake with the linseed + vitamin E diet was approximately 25 times higher than with the linseed diet.

\section{Milk Yield and Gross Composition}

As shown in Table 3, milk fat was low with the linseed diet, as it is classically observed when cows are fed high doses of UFA in a LF diet (Griinari et al., 1998). The 
Table 2. Daily intake of nutrients

\begin{tabular}{|c|c|c|}
\hline Nutrient & Linseed & $\begin{array}{l}\text { Linseed + } \\
\text { vitamin } \mathrm{E}^{1}\end{array}$ \\
\hline & & \\
\hline $\begin{array}{l}\text { DIVI } \\
\text { CP }\end{array}$ & 18.73 & \\
\hline CP & 2.80 & 2.82 \\
\hline $\mathrm{NDF}$ & 4.97 & 5.04 \\
\hline $\mathrm{ADF}$ & 2.67 & 2.70 \\
\hline \multicolumn{3}{|l|}{ Fatty acid } \\
\hline Total $^{2}$ & 1,083 & 1,092 \\
\hline$\leq \mathrm{C} 14^{2}$ & 7 & 7 \\
\hline $\mathrm{C} 16: 0$ & 106 & 107 \\
\hline C18:0 & 37 & 37 \\
\hline C18:1 & 219 & 221 \\
\hline C18:2 & 360 & 366 \\
\hline C18:3 & 348 & 348 \\
\hline$\alpha$-tocopherol, IU/d & 478 & 12,364 \\
\hline
\end{tabular}

${ }^{1} 12,000 \mathrm{IU}$ of supplemental vitamin $\mathrm{E} / \mathrm{d}$.

${ }^{2}$ Volative fatty acids of silage are not included.

ANOVA showed that the addition of vitamin $\mathrm{E}$ did not influence milk and protein yields. In contrast, milk fat yield and content were significantly increased with vitamin E supplementation. As described earlier in this paper, Charmley and Nicholson (1994), Focant et al. (1998), and Kay et al. (2005) observed a similar effect with dietary vitamin $\mathrm{E}$.

\section{Composition of Milk Fatty Acids}

Milk fatty acid profiles of cows fed the linseed diet were characterized by higher levels of trans-10 C18:1 compared with trans-11 C18:1 (Table 4). This is characteristic of cows fed high-concentrate, LF diets (Piperova et al., 2000, 2002; Peterson et al., 2003) and indicates that the linseed diet induced a shift in the ruminal biohydrogenation process. These results are consistent with those reported by Griinari et al. (1998). These

Table 3. Effect of oilseeds and vitamin E supplementation on milk yield and composition (means of individual milk samples from d 21 of each period)

\begin{tabular}{lccc}
\hline & \multicolumn{2}{c}{ Diet } \\
\cline { 2 - 3 } & Linseed & $\begin{array}{c}\text { Linseed }+ \\
\text { vitamin E }\end{array}$ & SE \\
\hline Yield, kg/d & & & \\
Milk & 27.4 & 26.3 & 0.63 \\
$4 \%$ FCM & 24.7 & 25.7 & 0.73 \\
Fat & $0.90^{\mathrm{b}}$ & $1.04^{\mathrm{a}}$ & 0.05 \\
Protein & 0.84 & 0.79 & 0.02 \\
Milk composition, g/kg & & & \\
Fat & $32.9^{\mathrm{b}}$ & $38.8^{\mathrm{a}}$ & 1.55 \\
Protein & 30.7 & 30.1 & 0.31 \\
\hline
\end{tabular}

${ }^{\mathrm{a}, \mathrm{b}}$ Values within a row with different superscripts differ $(P<0.05)$. Values with no superscript do not differ significantly.
Table 4. Effect of vitamin E supplementation on milk fatty acid composition and yield for cows fed a high-fat diet (means of individual milk samples from d 21 of each period)

\begin{tabular}{lccc}
\hline & \multicolumn{3}{c}{ Diet } \\
\cline { 2 - 3 } & Linseed & $\begin{array}{c}\text { Linseed }+ \\
\text { vitamin E }\end{array}$ & SE \\
\hline Fatty acid, g/100 g & & \\
C6:0 & 2.44 & 2.55 & 0.15 \\
C8:0 & 1.52 & 1.56 & 0.10 \\
C10:0 & 3.76 & 3.75 & 0.25 \\
C12:0 & 4.14 & 4.02 & 0.24 \\
C14:0 & 12.89 & 12.15 & 0.50 \\
C16:0 & 30.05 & 28.00 & 1.29 \\
C16:1 & 1.50 & 1.30 & 0.08 \\
C17:0 & 0.56 & 0.49 & 0.04 \\
C18:0 & 12.84 & 14.77 & 0.84 \\
C18:1 $c 9$ & 20.39 & 20.72 & 1.24 \\
C18:1 $c 11$ & 0.93 & 0.82 & 0.10 \\
C18:1 $t 6-t 8$ & 0.50 & 0.41 & 0.07 \\
C18:1 $t 9$ & 0.37 & 0.36 & 0.06 \\
C18: $t 10$ & $1.87^{\mathrm{a}}$ & $0.99^{\mathrm{b}}$ & 0.26 \\
C18:1 $t 11$ & 1.36 & 2.01 & 0.33 \\
C18:2 $c 9, t 11$ & 0.95 & 1.14 & 0.17 \\
C18:2 $c 9, c 12$ & 2.42 & 2.43 & 0.12 \\
C18:2 $t 10, c 12$ & 0.021 & 0.017 & 0.003 \\
C18:3 $c 9, c 12, c 15$ & 1.38 & 1.37 & 0.10 \\
C20:0 & 0.13 & 0.14 & 0.009 \\
CLA & 1.30 & 1.46 & 0.18 \\
Fatty acid, g/d & & & \\
C18:1 $t 11$ & $10.16^{\mathrm{b}}$ & $20.58^{\mathrm{a}}$ & 2.79 \\
C18:1 $t 10$ & $14.25^{\mathrm{a}}$ & $8.19^{\mathrm{b}}$ & 2.05 \\
C18:2 $c 9, t 11$ & $7.27^{\mathrm{b}}$ & $11.39^{\mathrm{a}}$ & 1.33 \\
C18:2 $t 10, c 12$ & 0.17 & 0.13 & 0.02 \\
\hline a,b Values within a row with different superscripts differ $(P<0.05)$ \\
Values with no superscript do not differ significantly. \\
\end{tabular}

authors examined the effect of fatty acid supplementation and the level of dietary fiber on MFD. Their LF diet containing high levels of UFA, which can be compared with the linseed diet in the present experiment, induced MFD and led to comparable levels of trans-11 C18:1 (2.52\% of total fatty acids), trans-10 C18:1 (2.90\% of total fatty acids), and cis-9, trans-11 C18:2 (1.10\% of total fatty acids) in milk, as compared with those obtained with the linseed diet.

The addition of vitamin $\mathrm{E}$ induced few significant changes in milk fatty acid profile, as was shown by the ANOVA (Table 4). The supplementation of the linseed diet with vitamin E significantly decreased the level of trans-10 C18:1 in milk, whereas it did not significantly increase the levels of vaccenic and rumenic acids. However, the graphs presented in Figure 1 show that the sequence of administration of vitamin $\mathrm{E}$ may influence its effect. When vitamin $\mathrm{E}$ was added simultaneously with linseed in the first period (Group 1), the level of trans-11 C18:1 was maintained, but trans-10 C18:1 remained low. This resulted in a high percentage of rumenic acid among the CLA isomers and a low percentage of trans-10, cis-12 C18:2 (data not shown). In the 

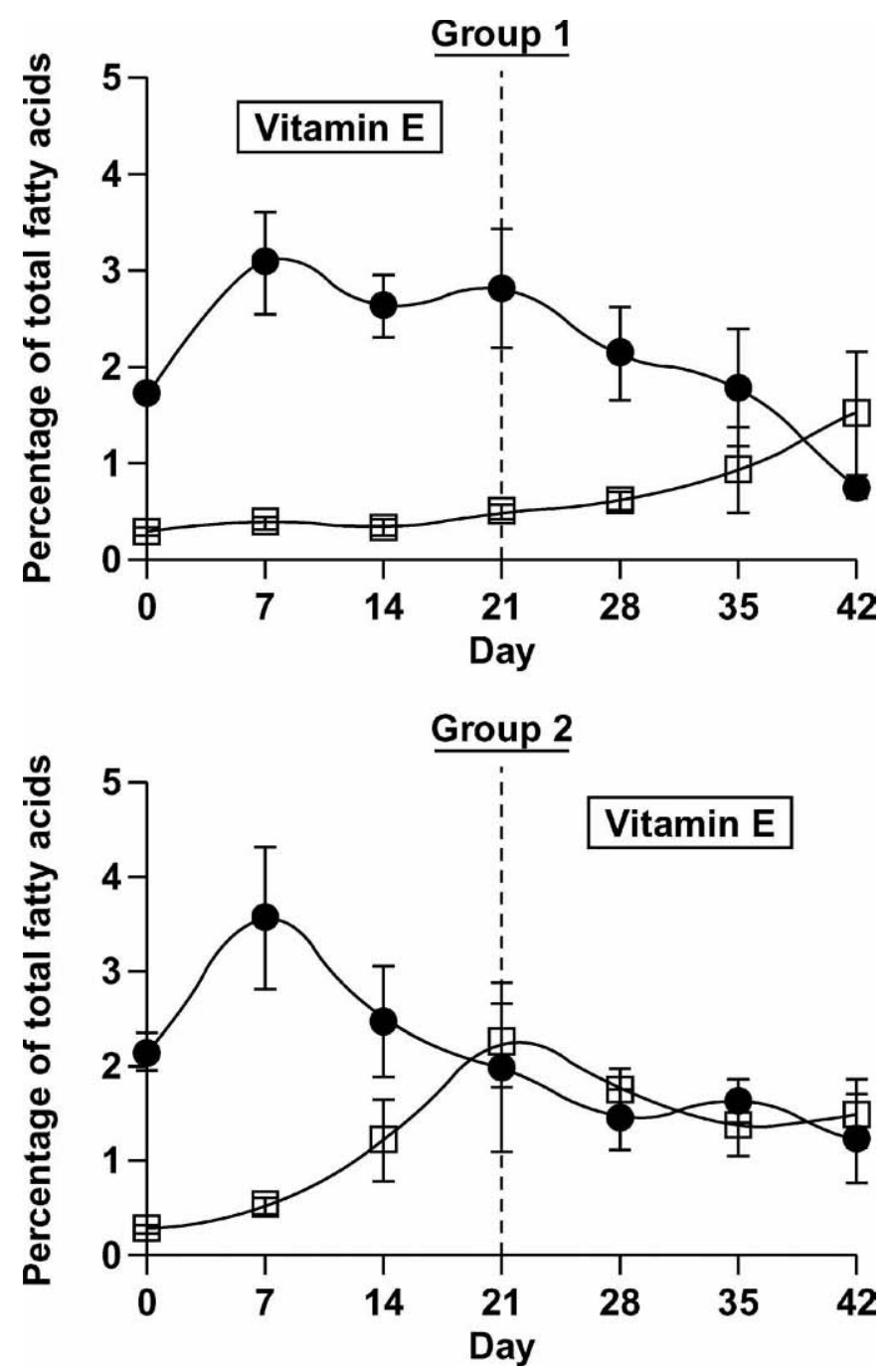

Figure 1. Effect of the sequence of administration of vitamin $\mathrm{E}$ $(12,000 \mathrm{IU} / \mathrm{d})$ on the concentration of trans-11 C18:1 () and trans$10 \mathrm{C} 18: 1(\square)$ in the milk of cows fed on a high-fat diet. Period $1=\mathrm{d}$ 1 to 21; Period $2=\mathrm{d} 22$ to 42 . Group $1=$ Vitamin $\mathrm{E}$ added during Period 1; Group 2 = Vitamin E added during Period 2.

second period, when Group 1 stopped receiving vitamin $\mathrm{E}$, trans-11 C18:1 decreased $(P<0.05)$ and trans -10 C18:1 increased $(P<0.05)$. Without vitamin E supplementation in the first period (Group 2), the shift occurred as expected: trans-10 C18:1 rose sharply $(P<$ $0.01)$ and trans-11 $\mathrm{C} 18: 1$ decreased $(P<0.05)$. However, when vitamin $\mathrm{E}$ was added at the beginning of the second period, it seemed to have only a limited effect. The levels of trans-11 C18:1 did not return to normal, even though a slight decrease was observed for trans$10 \mathrm{C} 18: 1(P=0.11)$. Thus, vitamin $\mathrm{E}$ seems to have an effect on the levels of trans-11 C18:1 only when it is incorporated in the diet simultaneously with the fat. Once the shift has occurred, vitamin $\mathrm{E}$ is no longer able
Table 5. Effect of vitamin E supplementation on milk conjugated linoleic acid isomers for cows fed on a high fat diet (means of individual milk samples from d 21 of each period)

\begin{tabular}{lccc}
\hline & \multicolumn{2}{c}{ Diet } \\
\cline { 2 - 3 } $\begin{array}{l}\text { Conjugated } \\
\text { linoleic acid }\end{array}$ & Linseed & $\begin{array}{c}\text { Linseed }+ \\
\text { vitamin E }\end{array}$ & SE \\
\hline & & & \\
& & & \\
cis, trans-isomers $^{1}$ & & & $\mathrm{~g})$ \\
7,9 & $10.32^{\mathrm{a}}$ & $8.21^{\mathrm{b}}$ & 0.48 \\
8,10 & 0.35 & 0.44 & 0.05 \\
9,11 & 72.36 & 75.69 & 1.85 \\
10,12 & 1.73 & 1.54 & 0.29 \\
11,13 & 2.44 & 2.54 & 0.10 \\
12,14 & 1.70 & 1.54 & 0.20 \\
trans, trans-isomers $_{7,9}$ & & & \\
8,10 & 0.54 & 0.49 & 0.06 \\
9,11 & 0.21 & 0.19 & 0.02 \\
10,12 & 1.72 & 1.51 & 0.11 \\
11,13 & 0.94 & 0.84 & 0.15 \\
12,14 & 5.39 & 4.81 & 0.70 \\
& 2.31 & 2.21 & 0.21 \\
\hline
\end{tabular}

${ }^{a, b}$ Values within a row with different superscripts differ $(P<0.05)$. Values with no superscript do not differ significantly.

${ }^{1}$ Geometrical isomers not separately determined.

to counteract completely this process. In terms of daily yields, vitamin $\mathrm{E}$ had a significantly positive effect on the production of vaccenic acid and rumenic acid, as well as a significantly negative effect on the production of trans-10 C18:1 (Table 4). This can be explained by the vitamin $\mathrm{E}$ effect on milk fat content and yield. Finally, few changes were observed regarding the proportion of the CLA isomers in milk fat (Table 5). Surprisingly, vitamin $\mathrm{E}$ decreased the proportion of the trans7, cis-9 isomer.

The effect of vitamin $\mathrm{E}$ on trans-10 C18:1 may be related to the increased level of milk fat. Figure 2 presents the correlation between milk fat content and milk trans-10 C18:1 level $\left(\mathrm{y}=3.6945 \mathrm{x}^{-0.124} ; \mathrm{R}^{2}=0.4475 ; P\right.$ $<0.001$ ). The same type of curve has been observed by Bauman and Griinari (2003). Figure 3 illustrates the inverse correlation between trans-10 C18:1 in milk and milk fat content in the form of a temporal figure. This inverse correlation supports the link between trans-10 C18:1 and MFD. Bauman and Griinari (2001) proposed that fatty acid intermediates produced by altered rumen biohydrogenation would be responsible for dietinduced MFD. Studies using postruminal infusion or intravenous administration of trans-10, cis-12 C18:2 have clearly demonstrated that this CLA isomer is a potent inhibitor of milk fat synthesis in dairy cows. However, Peterson et al. (2003) suggested that other biohydrogenation intermediates should also contribute to the low milk fat syndrome. Griinari et al. (1998) suggested earlier that trans-10 C18:1 itself also induces MFD. Unfortunately, because of the lack of pure trans- 


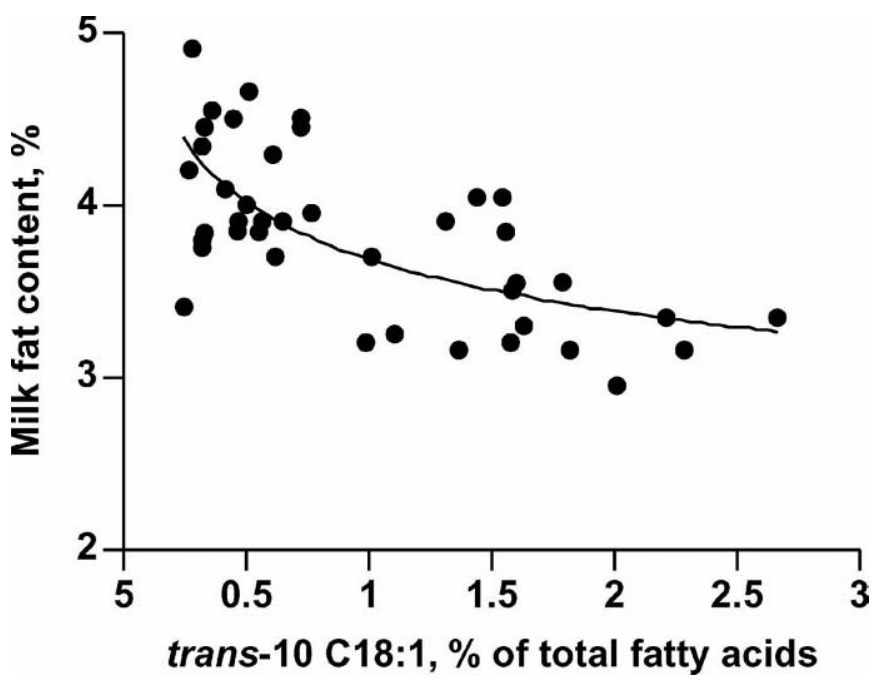

Figure 2. Relationship between the change in milk fat content and the trans-10 18:1 content of milk fat in cows fed on a high-fat diet.

$10 \mathrm{C} 18: 1$, there have been no studies to firmly confirm its role in diet-induced MFD.

Kay et al. (2005) recently tested the effect of dietary vitamin $\mathrm{E}$ (10,000 IU/d) on the biohydrogenation pathways of cows fed a TMR. Vitamin E significantly increased milk fat content by $6 \%$ and tended to increase trans-11 C18:1 concentration in plasma and numerically decreased plasma trans-10 C18:1. However, it had no effect on trans fatty acid isomers in milk. The apparent discrepancy with the results of the present experiment may be due to the fact that the shift in biohydrogenation pathways was less pronounced in the experiment of Kay et al. (2005) as shown by the trans-10 C18:1-to-trans-11 C18:1 ratio in milk [0.71 for Kay et al. (2005) vs. 1.38 for the present study].

So far, adding buffering agents to the diet is the only method proposed to prevent trans-10 isomer formation in the rumen and consequent MFD (Piperova et al., 2002). Unfortunately, dietary buffers will also decrease overall production of trans-C18:1 fatty acids in the rumen (Kalscheur et al., 1997); therefore, less vaccenic acid may be available in the mammary gland to be desaturated into rumenic acid.

Factors resulting in the shift of biohydrogenation pathways are well known (LF diets supplied with high levels of UFA or readily digestive carbohydrates). However, the mechanism through which it occurs is less clear. Rumen bacteria are sensitive to the content of plant oil in the diet, because the UFA contained in these oils have an unspecified toxic effect on the rumen bacteria. Biohydrogenation could be the mechanism through which rumen bacteria cope with the presence of UFA in their environment (Harfoot and Hazlewood,
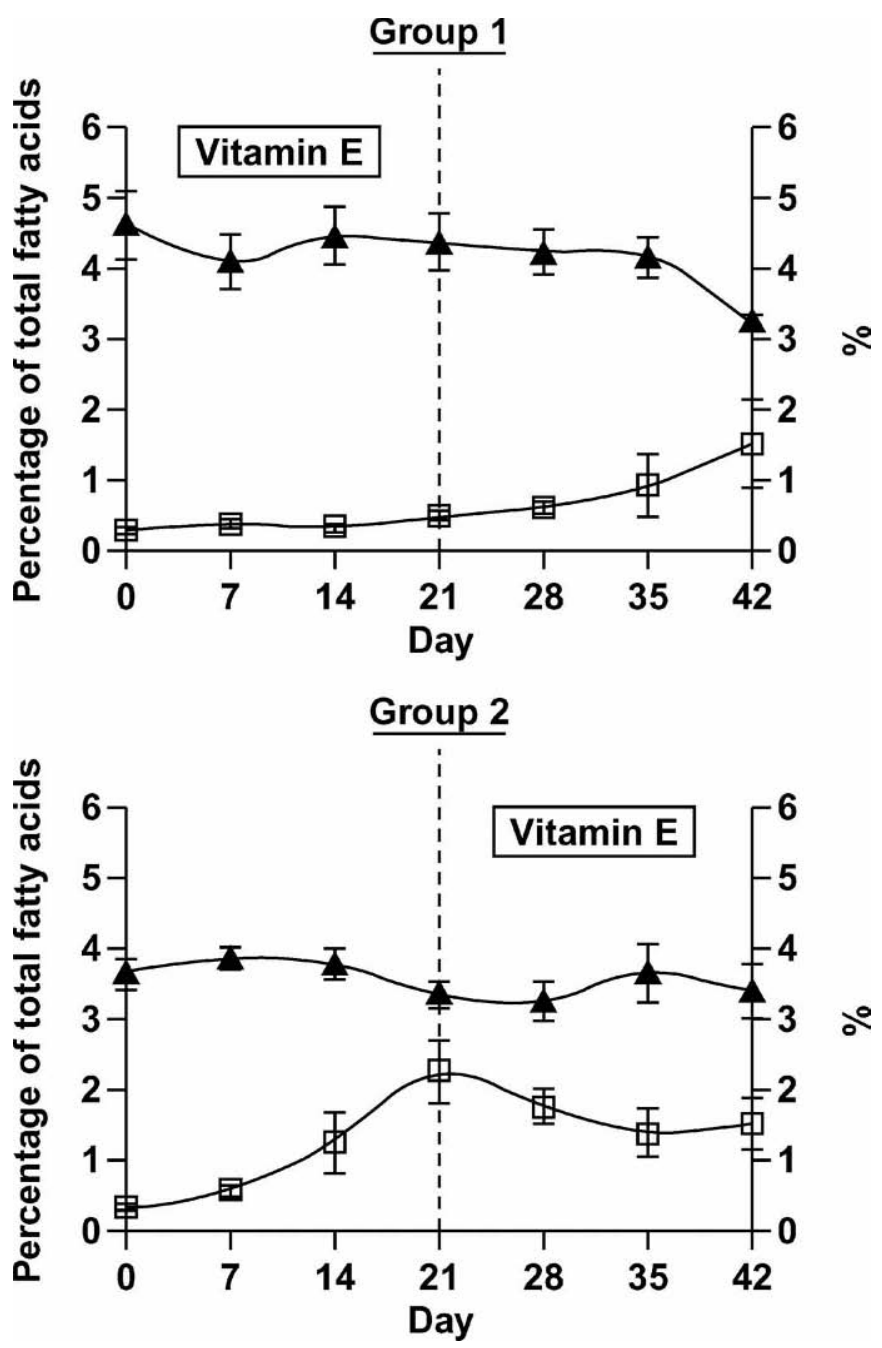

Figure 3. Temporal changes in milk fat content (A) and milk trans-10 C18:1 content $(\square)$ of cows fed a high-fat diet supplemented or not with vitamin E (12,000 IU/d). Period $1=\mathrm{d} 1$ to 21 ; Period $2=$ d 22 to 42. Group 1 = Vitamin $\mathrm{E}$ added during Period 1; Group $2=$ Vitamin E added during Period 2.

1988). However, when the load of UFA exceeds the biohydrogenation capacity, the growth as well as the function of rumen bacteria are impaired. Kim et al. (2002) showed that Megasphaera elsdenii, a bacterium producing trans-10 isomers, is more resistant to linoleic acid than Butyrivibrio fibrisolvens, a fiber-digesting bacterium that produces trans-11 isomers. Therefore, high-fat diets may be more detrimental to bacteria producing trans-11 isomers than those producing trans-10 isomers. Furthermore, high-concentrate, LF diets often result in increased lactic acid production, which eventually decreases ruminal $\mathrm{pH}$ (Griinari et al., 1998). The drop in ruminal $\mathrm{pH}$ may also contribute to altering ruminal microflora, leading to the shift in biohydrogenation pathways associated with LF diets. Fiber-digest- 
ing bacteria such as $B$. fibrisolvens would be sensitive to low $\mathrm{pH}$, as opposed to $M$. elsdenii, which utilizes lactate (Kung and Hession, 1995).

Vitamin E may counteract the shift in the biohydrogenation pathways by supporting the growth and function of trans-11-producing bacteria. Hino et al. (1993) observed that addition of safflower oil to a culture of mixed rumen bacteria depressed the growth of rumen microbes. However, addition of $\alpha$-tocopherol and $\beta$-carotene to the growth medium (each $5 \mathrm{mg} / \mathrm{L}$ ) alleviated the growth inhibition by the UFA. Moreover, addition of $\alpha$-tocopherol and $\beta$-carotene restored cellulose digestion, clearly by stimulating the growth of cellulolytic bacteria, which are supposed to be primarily responsible for the trans-11 biohydrogenation pathway (Martin and Jenkins, 2002).

The mechanism of vitamin $\mathrm{E}$ action is not known. In B. fibrisolvens, Hughes and Tove (1980a,b) identified compounds structurally close to $\alpha$-tocopherol- $\alpha$-tocopherolquinol and deoxy- $\alpha$-tocopherolquinol-as electron donors in the biohydrogenation of rumenic acid to vaccenic acid. In that context, vitamin $\mathrm{E}$ may intervene in 3 different ways to help B. fibrisolvens to cope with an excess of UFA. First, vitamin E might act in place of the electron donors to provide the electrons for the reduction of the cis bond of the conjugated diene. Second, vitamin $\mathrm{E}$ might be metabolized to these donors by microorganisms in the rumen. However, Hughes and Tove (1980a) did not put forward such roles of $\alpha$-tocopherol in their experiment. Third, vitamin $\mathrm{E}$ might act as an electron donor to restore $\alpha$-tocopherolquinol and deoxy- $\alpha$-tocopherolquinol. None of these hypotheses has been confirmed yet.

Another hypothesis would be that vitamin E inhibits the growth and function of bacteria that produce trans$10 \mathrm{C} 18: 1$. However, there is, at present, not much knowledge about this pathway; therefore, it is hard to say anything certain.

\section{CONCLUSIONS}

Cows fed LF diets supplied with high levels of UFA presented the typical symptoms of MFD associated with a shift in biohydrogenation pathways: low fat content and high level of trans-10 C18:1. However, in our experimental conditions, the addition of dietary vitamin $\mathrm{E}$ significantly increased milk fat content and yield and decreased the level of trans-10 C18:1. In addition, it managed to significantly increase the content of trans11 isomers in terms of yields. Interestingly, vitamin $\mathrm{E}$ was more efficient in limiting the trans-11 to trans10 shift because of fat supplementation when it was incorporated in the diet simultaneously with the fat. Once the shift had occurred, the subsequent addition of vitamin $\mathrm{E}$ was no longer able to completely counteract this process.

\section{ACKNOWLEDGMENT}

The authors gratefully acknowledge the financial support of the Ministry of Agriculture and Rural Affairs of the Walloon Region of Belgium (Project S-6049).

\section{REFERENCES}

Bauman, D. E., D. M. Barbano, D. A. Dwyer, and J. M. Griinari. 2000. Technical note: Production of butter with enhanced conjugated linoleic acid for use in biomedical studies with animal models. J. Dairy Sci. 83:2422-2425.

Bauman, D. E., and J. M. Griinari. 2001. Regulation and nutritional manipulation of milk fat: Low-fat milk syndrome. Livest. Prod. Sci. 70:15-29.

Bauman, D. E., and J. M. Griinari. 2003. Nutritional regulation of milk fat synthesis. Annu. Rev. Nutr. 23:203-227.

Belury, M. A. 2002. Dietary conjugated linoleic acid in health: Physiological effects and mechanisms of action. Annu. Rev. Nutr. 22:505-531.

Brubacher, G., W. Müller-Mulot, and D. A. T. Southgate. 1985. Methods for the Determination of Vitamins in Food. Elsevier Appl. Sci. Publ. Ltd., London, UK.

Charmley, E., and J. W. G. Nicholson. 1994. Influence of dietary fat source on oxidative stability and fatty acid composition of milk from cows receiving a low or high level of dietary vitamin E. Can. J. Anim. Sci. 74:657-664.

Christie, W. W. 1982. Lipid Analysis, 2nd ed. Pergamon Press, Oxford, UK.

Commission des Communautés Européennes. 1985. Recueil des Actes Agricoles, Tome VI/4, Harmonisation des Législations Aliments des Animaux. Office Publ. Officielles Commun. Eur. Luxembourg, Grand-Duché de Luxembourg.

Focant, M., E. Mignolet, M. Marique, F. Clabots, T. Breyne, D. Dalemans, and Y. Larondelle. 1998. The effect of vitamin E supplementation of cow diets containing rapeseed and linseed on the prevention of milk fat oxidation. J. Dairy Sci. 81:1095-1101.

Gerber, N. 1938. Praktische Milchprüfung, Einschliechend die Kontrolle von Molkerei Produkten. Wych, Berne, Switzerland.

Goering, H. K., and P. J. Van Soest. 1970. Forage Fiber Analyses (Apparatus, Reagents, Procedure, and Some Applications). Agric. Handbook No. 379. ARS-USDA, Washington, DC.

Griinari, J. M., and D. E. Bauman. 1999. Biosynthesis of conjugated linoleic acid and its incorporation into meat and milk of ruminants. Pages 180-200 in Advances in Conjugated Linoleic Acid. Vol. 1. AOCS Press, Champaign, IL.

Griinari, J. M., D. A. Dwyer, M. A. McGuire, D. E. Bauman, D. L. Palmquist, and K. V. V. Nurmela. 1998. Trans-octadecenoic acids and milk fat depression in lactating dairy cows. J. Dairy Sci. 81:1251-1261.

Harfoot, C. G., and G. P. Hazlewood. 1988. Lipid Metabolism in the Rumen. Pages 285-321 in The Rumen Microbial Ecosystem. P. N. Hobson, ed. Elsevier Applied Science, New York, NY.

Hino, T., N. Andoh, and H. Ohgi. 1993. Effects of $\beta$-carotene and $\alpha$ tocopherol on rumen bacteria in the utilization of long-chain fatty acids and cellulose. J. Dairy Sci. 76:600-605.

Hughes, P. E., and S. B. Tove. 1980a. Identification of an endogenous electron donor for biohydrogenation as $\alpha$-tocopherolquinol. J. Biol. Chem. 255:4447-4452.

Hughes, P. E., and S. B. Tove. 1980 b. Identification of deoxy- $\alpha$-tocopherolquinol as another endogenous electron donor for biohydrogenation. J. Biol. Chem. 255:11802-11806.

INRA. 1988. Alimentation des Bovines, Ovins et Caprins. INRA, Paris, France.

Kalscheur, K. F., B. B. Teter, L. S. Piperova, and R. A. Erdman. 1997. Effect of dietary forage concentration and buffer addition on 
duodenal flow of trans-C18:1 fatty acids and milk fat production in dairy cows. J. Dairy Sci. 80:2104-2114.

Kay, J. K., J. R. Roche, E. S. Kolver, N. A. Thomson, and L. H. Baumgard. 2005. A comparison between feeding systems (pasture and TMR) and the effect of vitamin E supplementation on plasma and milk fatty acid profiles in dairy cows. J. Dairy Res. 72:322-332.

Kim, Y. J., R. H. Liu, J. L. Rychlik, and J. B. Russell. 2002. The enrichment of a ruminal bacterium (Megasphaera elsdenii YJ-4) that produces the trans-10, cis-12 isomer of conjugated linoleic acid. J. Appl. Microbiol. 92:976-982.

Kung, L., Jr., and A. O. Hession. 1995. Preventing in vitro lactate accumulation in ruminal fermentations by inoculation with $\mathrm{Meg}$ asphaera elsdenii. J. Anim. Sci. 73:250-256.

Martin, S. A., and T. C. Jenkins. 2002. Factors affecting conjugated linoleic acid and trans-C18:1 fatty acid production by mixed ruminal bacteria. J. Anim. Sci. 80:3347-3352.

Palmquist, D. L. 1984. Use of fats in diets for lactating dairy cows. Pages 357-381 in Fats in Animal Nutrition. J. Wiseman, ed. Butterworths, London, UK.

Palmquist, D. L., A. D. Beaulieu, and D. M. Barbano. 1993. Feed and animal factors influencing milk fat composition. J. Dairy Sci. $76: 1753-1771$.
Peterson, D. G., E. A. Matitashvili, and D. E. Bauman. 2003. Dietinduced milk fat depression in dairy cows results in increased trans-10, cis-12 CLA in milk fat and coordinate suppression of mRNA abundance for mammary enzymes involved in milk fat synthesis. J. Nutr. 133:3098-3102.

Piperova, L. S., J. Sampugna, B. B. Teter, K. F. Kalscheur, M. P. Yurawecz, Y. Ku, K. M. Morehouse, and R. A. Erdman. 2002. Duodenal and milk trans-octadecenoic acid and conjugated linoleic acid (CLA) isomers indicate that postabsorptive synthesis is the predominant source of cis-9-containing CLA in lactating dairy cows. J. Nutr. 132:1235-1241.

Piperova, L. S., B. B. Teter, I. Bruckental, J. Sampugna, S. E. Mills, M. P. Yurawecz, J. Fritsche, K. Ku, and R. A. Erdman. 2000. Mammary lipogenic enzyme activity, trans fatty acids and conjugated linoleic acids are altered in lactating dairy cows fed a milk fat-depressing diet. J. Nutr. 130:2568-2574.

Yurawecz, M. P., J. A. G. Roach, N. Sehat, and M. M. Mossoba. 1998. Identification of conjugated linoleic isomers in cheese by gas chromatography, silver-iron high-performance liquid chromatography and mass spectral reconstructed ion profiles. Comparison of chromatographic elution sequences. Lipids 33:963-971. 